\title{
High Proportions of CD4+ T Cells among Residual Bone Marrow T Cells in Childhood Acute Lymphoblastic Leukemia Are Associated with Favorable Early Responses
}

\author{
Imke Lustfeld $^{a} \quad$ Bianca Altvater $^{a} \quad$ Martina Ahlmann ${ }^{a}$ Sandra Ligges ${ }^{b}$ \\ Peter Brinkrolfa Annegret Rosemann ${ }^{a} \quad$ Anja Moericke ${ }^{c} \quad$ Claudia Rossig $^{a}$ \\ ${ }^{a}$ Department of Pediatric Hematology and Oncology, University Children's Hospital Münster, and ${ }^{\mathrm{b}}$ Institute \\ of Biostatistics and Clinical Research, University Hospital Münster, Münster, and 'Department of Pediatrics, \\ University Medical Center Schleswig-Holstein, Kiel Campus, Kiel, Germany
}

\section{Key Words}

Acute lymphoblastic leukemia · Bone marrow · Lymphocyte subpopulations $\cdot$ Regulatory $T$ cells $\cdot T$ cells

\begin{abstract}
Residual nonmalignant $\mathrm{T}$ cells in the bone marrow of patients with acute leukemias may be involved in active immune responses to leukemic cells. Here, we investigated the phenotypic signature of $\mathrm{T}$ cells present at diagnosis in 39 pediatric patients with acute lymphoblastic leukemia (ALL) treated within standardized ALL-BFM study protocols. Previously described age associations of lymphocyte subpopulations in the peripheral blood of healthy children were reproduced in leukemic bone marrow. Analysis of individual lymphocyte parameters and risk-associated variables using univariate linear regression models revealed a correlation of higher CD4/CD8 ratios at diagnosis with a favorable bone marrow response on day 15 . Separate analysis of CD4+ cells with the CD4+CD25 hiFoxP3+ $T_{\text {reg }}$ cell phenotype showed that the association was caused by non- $\mathrm{T}_{\text {reg }} \mathrm{CD} 4+$ cells. The association of higher $C D 4 / C D 8$ ratios with a favorable bone marrow response on day 15 of treatment persisted in a co-
\end{abstract}

\section{KARGER}

E-Mail karger@karger.com

www.karger.com/aha hort extended to 69 patients. We conclude that CD4+ non$\mathrm{T}_{\text {reg }}$ cells in leukemic bone marrow at diagnosis may have a role in early response to treatment. Prospective analysis of the $C D 4 / C D 8$ ratio in a large cohort of pediatric patients is now needed. Moreover, future experiments will establish the functional role of the individual $T$ cell subsets in immune control in pediatric ALL.

Copyright $\odot 2013$ S. Karger AG, Basel

\section{Introduction}

Diagnostic bone marrow (BM) in acute lymphoblastic leukemia (ALL) contains variable proportions of nonmalignant lymphocytes, and flow cytometry allows differentiation of these normal lymphocytes from the predominant clonal lymphoblast population. Comparable to the local tumor niche of solid tumors [1-4], disease-associated immune responses in leukemias may localize to the BM microenvironment where nonmalignant lymphocytes are exposed to large numbers of leukemic cells. Besides its role in hematopoiesis, BM functions as a secondary lymphoid organ where both T cell priming and mem-
(C) 2013 S. Karger AG, Basel

$0001-5792 / 14 / 1311-0028 \$ 39.50 / 0$ 
ory responses to blood-borne antigens take place [5]. In various cancers, $\mathrm{BM}$ has been found to contain memory $\mathrm{T}$ cells with antitumor reactivity [6-8]. Thus, nonmalignant lymphocytes in leukemic BM may reflect an attempt to mount an antileukemic host immune response. Alternatively or in addition, BM lymphocytes with immunomodulatory properties may contribute to local immune evasion of leukemic blasts and thereby promote the apparently unrestricted expansion of the leukemic clone [913]. Characterization of the cellular micromilieu in leukemic BM may lead to a better understanding of the ineffective antileukemic immunity and provide a basis for the development of immune-based strategies. Here, we investigated the phenotypic signature of residual nonmalignant BM T cells and innate effector cells present at diagnosis in pediatric patients with ALL. Specifically, we analyzed whether individual subpopulations of cells are overrepresented or associated with individual disease parameters and response.

\section{Methods}

\section{Patients and Treatment}

BM was obtained at diagnosis from 39 pediatric patients with ALL treated at our institution. Diagnosis, risk group assignment, and treatment were performed according to the Berlin-FrankfurtMünster Study Group multicenter trials ALL-BFM $2000(\mathrm{n}=31)$ and ALL BFM $95(n=8)$. Philadelphia chromosome-positive or MLL-rearranged leukemias and ALL in patients with Down syndrome were excluded. This study was approved by the University of Münster Ethical Board, and informed consent was obtained from the patients and/or their legal guardians in accordance with the Declaration of Helsinki. Response assessment was done in peripheral blood on day 8 of prednisone therapy and on days 15 and 33 in BM [14]. The BM response on day 15 was classified as favorable (M1 marrow, $<5 \%$ blasts) or unfavorable (M2 marrow, $\geq 5$ and $<25 \%$, and M3 marrow, $\geq 25 \%$ blasts). Induction failure was defined as $\geq 5 \%$ BM blasts on day 33. ALL-BFM 2000 study patients were stratified into the risk groups SR (standard risk), MR (medium risk), and HR (high risk) according to minimal residual disease assessment by PCR [15]. For data validation, CD4/CD8 ratios were retrospectively extracted from routine diagnostic immunophenotyping in a series of 30 additional patients from our institution treated between 2010 and 2012 within the current AIEOPALL-BFM trial.

\section{Multicolor Flow Cytometry}

Mononuclear cells were isolated from freshly aspirated BM by density gradient centrifugation and either used directly or frozen in liquid nitrogen. For immunophenotyping, cells were stained with monoclonal antibodies conjugated to fluorescein isothiocyanate (FITC), phycoerythrin (PE), PE-cyanin 7 (PE-Cy7), peridinin chlorophyll protein (PerCP), allophycocyan (APC), or APC-Cy7 or APC-H7 (all from Becton Dickinson, San Jose, Calif., USA). Antibodies were used in the following combinations: panel 1,
CD3-PerCP/CD56-PE-Cy7/TCR $\alpha \beta$-FITC/TCR $\gamma \delta$-PE/CD $86-$ APC, HLA-DR-APC-Cy7; panel 2, CD3-PerCP/CD4-FITC/CD8APC-cy7/cyFoxP3-APC/CD25-PE-Cy7, and panel 3, CD3-PerCP/ CD4-FITC/CD8-APC-Cy7/CD28-PE, CCR7-APC, CD45RO-PECy7. After analysis of the first 13 patients, panels 2 and 3 were replaced by the following simplified panel: CD4-PerCP/CD8-APCCy7/CD25-FITC/CD45RO-PE/CCR7-PE-Cy7/FoxP3-APC. The routine diagnostic immunophenotyping panel that was used for validation of $\mathrm{CD} 4 / \mathrm{CD} 8$ ratio data included CD4-FITC, CD3-PECy7, and CD8-APC-H7. Intracellular FoxP3 staining was performed as previously described [16]. For retrospective analysis of CD4/CD8 ratios from diagnostic immunophenotyping data, acquisition of a minimum number of $250 \mathrm{CD} 3+$ cells was requested. Cell acquisition was performed using a BD FACS Canto flow cytometer (Becton Dickinson), followed by analysis using FACS DIVA software (BD).

\section{Statistical Analysis}

Statistical analyses were performed using IBM SPSS ${ }^{\circledR}$ Statistics 20 for Windows (IBM Corporation, Somers, N.Y., USA). Inferential statistics are intended to be exploratory (hypotheses generating), not confirmatory, and were interpreted accordingly. Thus, p values were interpreted in Fisher's sense, representing the metric weight of evidence against the respective null hypothesis of no effect. Neither a global significance level nor local levels were determined. $\mathrm{p} \leq 0.05$ was considered statistically significant and $\mathrm{p} \leq$ 0.01 was considered highly statistically significant. Different univariate linear regression models for each cell marker (dependent variable) were created in order to investigate the relationship between the acquired cell data and the patients' individual data. Due to small sample numbers, highly correlated variables among the patients' personal data (independent variables) were fit separately in different models. In order to search for correlations within in the patients' data, contingency tables and $\chi^{2}$ tests were used. All noticeable associations detected between a cell marker and a dichotomous variable in the regression models were additionally tested by means of a Student $t$ test. In order to identify the prognostic relevance of the acquired cell data, logistic regression models were created in which prognostic factors were set as dependent variables to examine if they were predictable by certain cell parameters.

\section{Results}

\section{Patient Characteristics}

Our cohort included 39 patients with ALL. The detailed clinical characteristics are presented in table 1. Four patients relapsed, 2 of whom had T cell ALL. All were treated with salvage chemotherapy, and 3 received an allogeneic hematopoietic stem cell transplant from a matched donor. All of the relapse patients were alive and well and in complete remission at the time of reporting, and one was still undergoing relapse chemotherapy. The median follow-up for all patients from the first diagnosis of leukemia was 80 months (range 36-225). Statistical 
Table 1. Characteristics of ALL patients

\begin{tabular}{|c|c|}
\hline \multicolumn{2}{|l|}{ Age } \\
\hline Median age (range), months & $60(25-198)$ \\
\hline \multicolumn{2}{|l|}{ Age at diagnosis } \\
\hline $2-4$ years & 20 \\
\hline $5-10$ years & 14 \\
\hline $11-16$ years & 5 \\
\hline \multicolumn{2}{|l|}{ Gender } \\
\hline Male & 22 \\
\hline Female & 17 \\
\hline Male-to-female ratio & 1.3 \\
\hline \multicolumn{2}{|l|}{ Phenotype } \\
\hline B cell precursor & 36 \\
\hline $\mathrm{T}$ cell, $\mathrm{n}$ & 3 \\
\hline \multicolumn{2}{|c|}{ ETV6-RUNX1 gene rearrangement in B cell precursor $A L L$} \\
\hline Present & 13 \\
\hline Absent & 23 \\
\hline \multicolumn{2}{|l|}{ CNS involvement } \\
\hline Positive & 1 \\
\hline Negative & 38 \\
\hline \multicolumn{2}{|l|}{ Prednisone response } \\
\hline Good & 35 \\
\hline Poor & 4 \\
\hline \multicolumn{2}{|l|}{ Response on BM day 15} \\
\hline M1 & 30 \\
\hline $\mathrm{M} 2 / \mathrm{M} 3$ & 9 \\
\hline \multicolumn{2}{|l|}{ Response on BM day 33} \\
\hline M1 & 38 \\
\hline $\mathrm{M} 2 / \mathrm{M} 3$ & 1 \\
\hline \multicolumn{2}{|c|}{ Risk stratification (ALL-BFM 2000 study patients) } \\
\hline$S R$ & 11 \\
\hline$M R$ & 16 \\
\hline$H R$ & 4 \\
\hline \multicolumn{2}{|l|}{ Outcome } \\
\hline Relapse-free survival & 35 \\
\hline Survival after relapse & 4 \\
\hline
\end{tabular}

analysis by means of cross tables and $\chi^{2}$ tests revealed a strong correlation between both T-ALL and higher white cell counts with older age at diagnosis. Moreover, children with a poor response to prednisone more often had higher residual BM blast counts on day 15 ( $\geq 5 \%$, M2 or M3 marrow) than those with a good response. These observations are consistent with published data from large cohorts of ALL-BFM study patients [14].

\section{Distribution of Residual Lymphocyte Subpopulations in Patients at the Primary Diagnosis of ALL}

Precise definition of normal lymphocyte subpopulations against the background of the malignant clone was possible by 6-color flow cytometry in all patients including those with $\mathrm{T}$ and $\mathrm{B}$ lineage leukemias. Quantitative comparisons of individual subpopulations with normal values are limited by the contamination of the lymphocyte gate with leukemic cells and by the lack of normal values for BM lymphocyte subpopulations in childhood. Therefore, we focused on established ratios and proportions of individual lymphocyte subsets. Since published data shows substantial age variations in the relative and absolute sizes of normal lymphocyte subpopulations in childhood both in peripheral blood $[17,18]$ and in BM [19], parameters were analyzed within three defined age groups of $2-5$ years, $5-10$ years, and $>10$ years. The CD4/ CD8 ratio is an established parameter used to represent the relative distribution of $\mathrm{CD} 4+$ and $\mathrm{CD} 8+\mathrm{T}$ cells. The median CD4/CD8 ratio in our patient cohort was 1.22 (range 0.42-2.63). Analogous to previous reports in peripheral blood, the median values for CD4/CD8 ratios were higher in 2- to 5-year-old children than in older children $(p=0.014)$ (fig. 1a). Next, we determined the relative frequencies of individual subpopulations among residual $\mathrm{T}$ cells. A median of $4.77 \%$ (range $0.65-23.97$ ) of $\mathrm{BM}$ CD3+ T cells in ALL coexpressed the activation marker HLA-DR+. No differences in the proportions of HLA$\mathrm{DR}+\mathrm{T}$ cells were found between children aged $2-5$ years and those aged $5-16$ years $(\mathrm{p}=0.78)$ (fig. $1 \mathrm{~b})$. The predominant subsets among both CD4+ and CD8+ T cells had a naive $\left(\mathrm{T}_{\mathrm{N}}\right) \mathrm{T}$ cell phenotype (CD45RO-CCR7+) [20] (fig. 1c, d). A noticeable increase in antigen-experienced, more differentiated, effector memory $\left(\mathrm{T}_{\mathrm{EM}}\right) \mathrm{T}$ cells in older children was found among CD4+ T cells $(\mathrm{p}=$ 0.03 ) (fig. 1c, d). For quantitative comparisons of innate immune effector cells despite the presence of leukemic cells within the lymphocyte gate, we determined the relative proportions of T cells bearing $\gamma \delta$ T cell receptors $(\gamma \delta$ $\mathrm{T}$ cells) and CD56+CD3+ natural killer $\mathrm{T}$ (NKT) cells among CD3+ T cells. For CD3-negative, CD56+ cells (NK cells), the ratio to $\mathrm{T}$ cells was calculated. $\gamma \delta \mathrm{T}$ cell proportions tended to be higher in older children ( $\mathrm{p}=$ 0.055) (fig. 1e-g). The proportion of NKT cells among CD3+ cells was noticeably higher in older children (fig. 1e-g), whereas the NK cell/T cell ratio did not vary between age groups $(p=0.076)$.

\section{$B M C D 4+C D 25^{h i} F o x P 3+T_{\text {reg }}$ Cells at the Primary Diagnosis of $A L L$}

Via intracellular costaining of CD4+CD25 $5^{\text {hi }} \mathrm{T}$ cells with a FoxP3-specific antibody, a population of $\mathrm{T}$ cells with the $\mathrm{T}_{\text {reg }}$ phenotype (referred to as ' $\mathrm{T}_{\text {reg }}$ cells') was identified in all patients (fig. $2 \mathrm{a}-\mathrm{d}$ ). Among CD4+ T cells, a median of $4.4 \%$ (range $0.8-10.7$ ) coexpressed $\mathrm{CD} 25^{\text {hi }}$ FoxP3. No noticeable difference was found between patients below and above the ages of 5 years (fig. 2e,
30

Acta Haematol 2014;131:28-36 DOI: $10.1159 / 000351429$
Lustfeld/Altvater/Ahlmann/Ligges/ Brinkrolf/Rosemann/Moericke/Rossig 


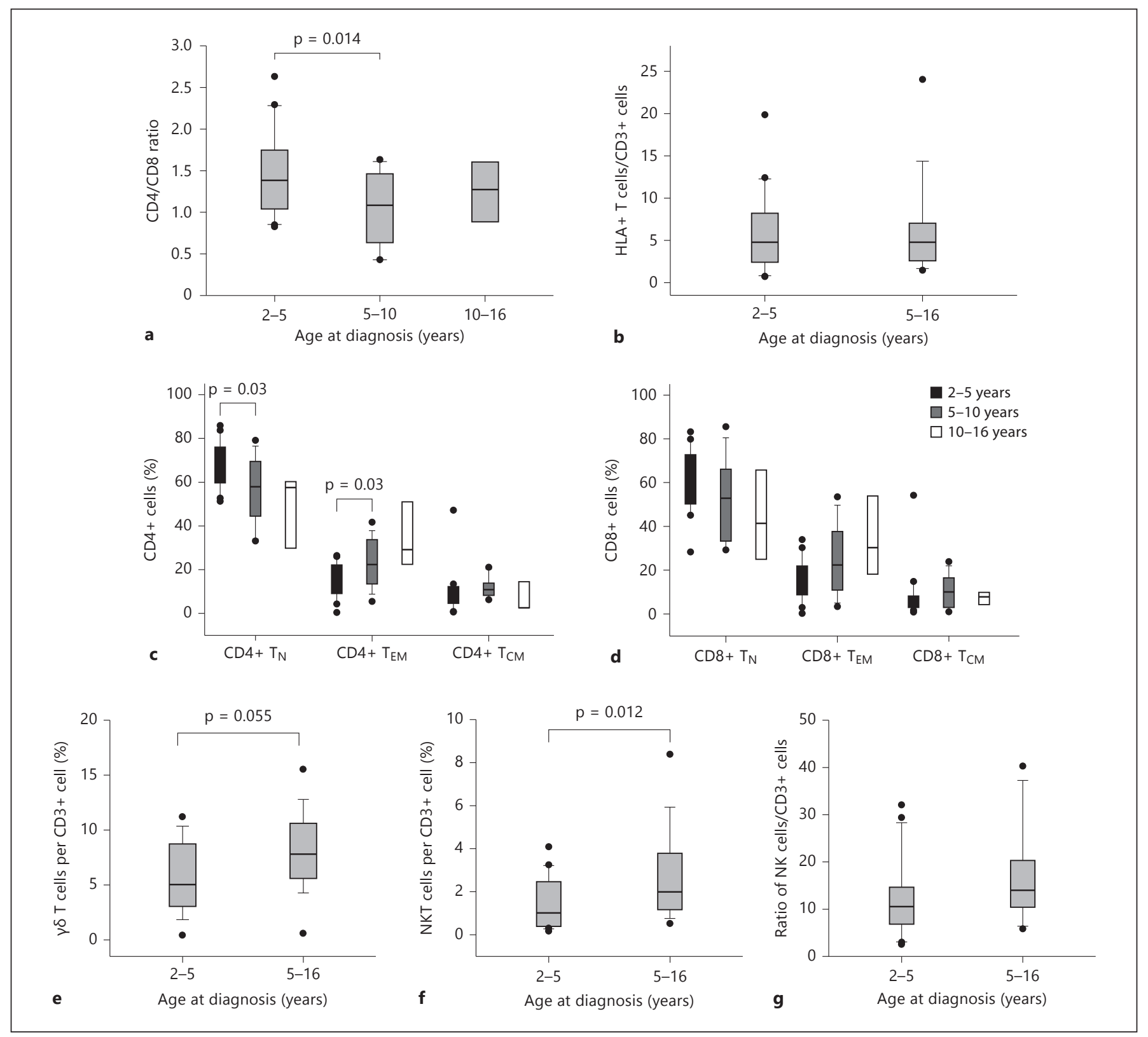

Fig. 1. BM lymphocyte subpopulations in patients with ALL. a Ratio of CD4+ T cells to CD8+ T cells in the BM of 39 patients with ALL according to age. $\mathbf{b}$ Proportion of HLA-DR+ cells to $\mathrm{CD} 3+\mathrm{T}$ cells in the BM of 13 patients with ALL according to age. c, d Proportion of naive ( $\left.\mathrm{T}_{\mathrm{N}} ; \mathrm{CD} 45 \mathrm{RO}-\mathrm{CCR} 7+\right)$, central memory $\left(\mathrm{T}_{\mathrm{CM}} ; \mathrm{CD} 45 \mathrm{RO}+\mathrm{CCR} 7+\right)$, and effector memory $\left(\mathrm{T}_{\mathrm{EM}}\right.$; CD45RO+CCR7-) cells as a fraction of CD4+ and CD8+ T cells

f). The majority of $\mathrm{T}$ cells with the $\mathrm{T}_{\text {reg }}$ phenotype had a naive phenotype by expression of CCR7 in the absence of CD45RO [21] (fig. 2e, f). The results were not noticeably different between children below and above 5 years of age $(\mathrm{p}=0.909)$.

Residual BM T Cells in Childhood ALL in the BM of 39 patients with ALL according to age. Proportion of $\gamma \delta \mathrm{TCR}+$ cells (e) and CD56+ NKT cells (f) to CD3+ T cells in the BM of 39 patients with ALL, and ratio of CD3-CD56+ NK cells to CD3+ T cells $(\mathbf{g})$ in 13 patients with ALL, according to age. The lines indicate the median proportions of the respective cell population, and the boxes represent the 25 th and 75 th percentiles.

\section{Associations between Individual Lymphocyte Subsets and Patient-Related Variables}

To identify potential associations of residual BM lymphocyte subpopulations with known risk factors of the disease, we categorized our patient cohort according 


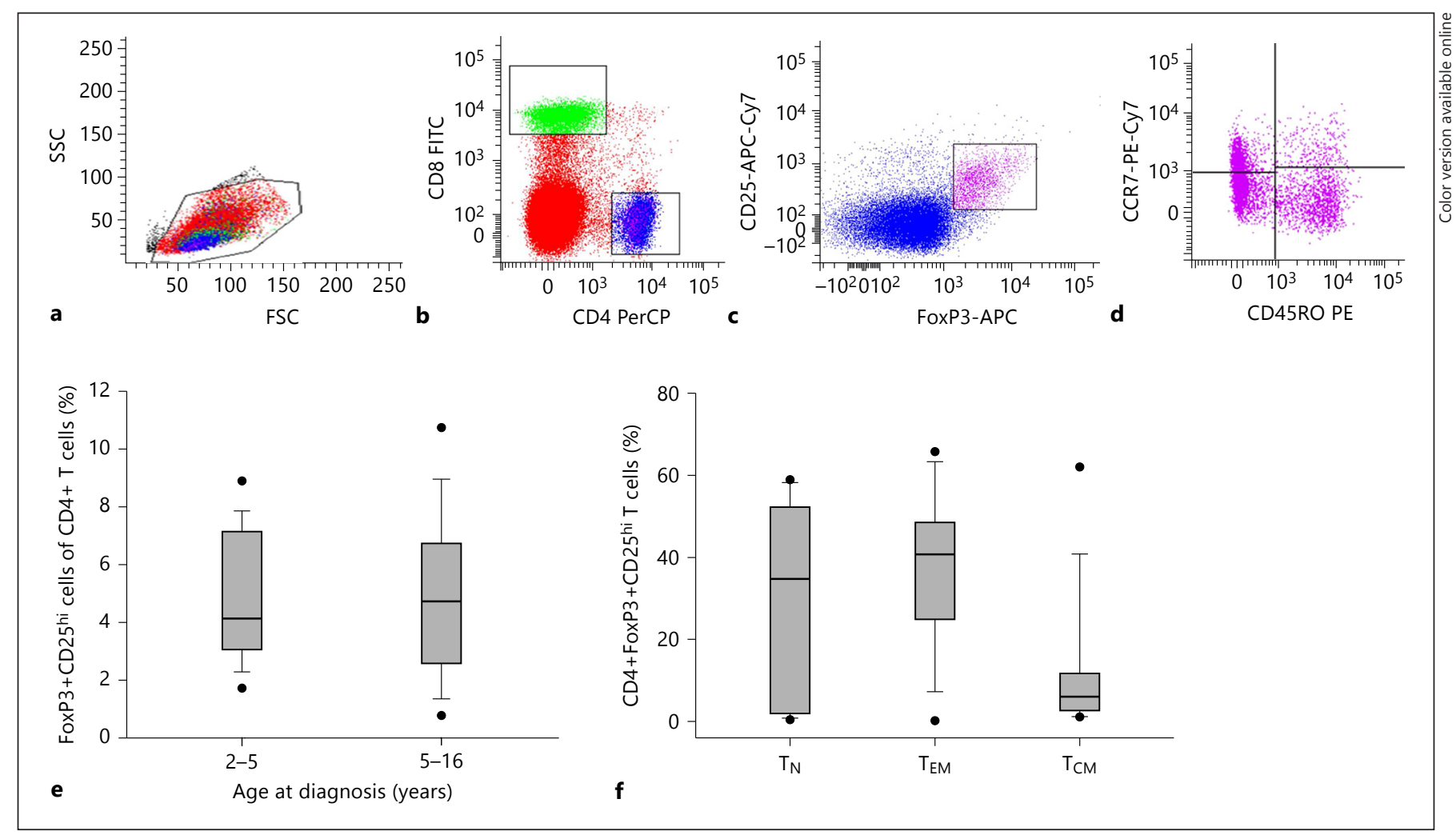

Fig. 2. $\mathrm{BM} C D 4+\mathrm{CD} 25^{\text {hi }}$ FoxP3 $+\mathrm{T}_{\text {reg }}$ cells in patients with ALL. a-d Gating strategy used to quantitate CD4+CD2 $5{ }^{\text {hi }}$ FoxP3 $+\mathrm{T}_{\text {reg }}$ cells as well as CD45RO+ and RO-negative $\mathrm{T}_{\text {reg }}$ cell subpopulations (1 representative example). Within the lymphocyte gate containing a predominant population of leukemic cells, a gate was set on CD4+ T cells. CD4+CD25 $5^{\text {hi }}$ FoxP3 $+\mathrm{T}_{\text {reg }}$ cells were quantified with-

to previously defined patient-related variables, including age, gender, phenotype (B cell precursor or T-ALL), ETV6-RUNX1 gene rearrangement in B cell precursor ALL, and CNS involvement [14]. A comprehensive analysis including all individual lymphocyte parameters revealed that patients with ETV6-RUNX-1-rearranged leukemias had a higher proportion of CD4+ T cells with naive $\left(\mathrm{T}_{\mathrm{N}}\right.$, median $74.1 \%$ ) versus $\mathrm{T}_{\mathrm{EM}}$ (median $11.5 \%$ ) phenotypes than those with ETV6-RUNX1-negative BCP-ALL (median $59.3 \% \mathrm{~T}_{\mathrm{N}}$ vs. $22.5 \% \mathrm{~T}_{\mathrm{EM}}$ cells, $\mathrm{p}=$ 0.0002 ). This observation may at least partly be explained by the association of both ETV6-RUNX1-positive leukemias and higher numbers of naive T cells with younger age (fig. 1c, d). In our cohort, children with ETV6-RUNX1-rearranged and ETV6-RUNX1-negative ALL had median ages of 59 versus 82 months ( $\mathrm{p}=$ $0.115)$.

Moreover, noticeable differences were found between patients with T-ALL and those with BCP-ALL. Consis- in this gate and subcategorized by coexpression of CCR7 and CD45RO. Relative proportion of $\mathrm{T}_{\text {reg }}$ cells as a fraction of $\mathrm{CD} 4+\mathrm{T}$ cells (e), and relative proportion of $\mathrm{T}_{\text {reg }}$ cells with naive, $\mathrm{T}_{\mathrm{EM}}$, and $\mathrm{T}_{\mathrm{CM}}$ phenotypes (f) in 39 patients with ALL. The lines indicate the median proportions of the respective cell populations, and the boxes represent the 25 th and 75 th percentiles.

tent with the subtype distribution of childhood ALL, only 3 leukemias had a $\mathrm{T}$ cell phenotype, limiting the power of analysis. Since patients with T cell leukemias were older (7, 9 and 15 years), and CD4/CD8 ratios were noticeably different between children aged $<5$ years and those aged $\geq 5$ years (fig. 1a), only children with B cell precursor leukemias aged $\geq 5$ years $(n=16)$ were included in this comparison. CD4/CD8 ratios were noticeably lower in patients with $\mathrm{T}$ cell ALL than in patients aged $\geq 5$ years with $\mathrm{B}$ cell precursor leukemia (fig. $3 \mathrm{a}, \mathrm{p}=0.05$ ). Regarding the proportion of cells with the $\mathrm{T}_{\text {reg }}$ cell phenotype, no differences between age groups were found; therefore, the entire cohort of patients with BCP-ALL was compared with the T-ALL patients. Patients with T-ALL had higher BM $\mathrm{T}_{\text {reg }}$ cell proportions than those with BCP-ALL (fig. $3 \mathrm{~b}$, $\mathrm{p}=0.03)$ and a higher proportion of T cells with an activated phenotype (HLA-DR+) $(\mathrm{p}=0.008)$. No further associations were found between individual lymphocyte subsets and patient-related variables.
Lustfeld/Altvater/Ahlmann/Ligges/ Brinkrolf/Rosemann/Moericke/Rossig 
Fig. 3. $\mathrm{CD} 4 / \mathrm{CD} 8$ cell ratios and $\mathrm{T}_{\mathrm{reg}}$ cell proportions differ between patients with BCP-ALL and T-ALL phenotypes. a Ratio of CD4+ T cells to CD8+ T cells in the BM of 16 patients aged $\geq 5$ years with ALL and 3 patients with T-ALL. b Relative proportion of $\mathrm{BM} \mathrm{T}_{\text {reg }}$ cells as a fraction of CD4+ $\mathrm{T}$ cells in 36 patients with BCP-ALL and 3 patients with T-ALL.

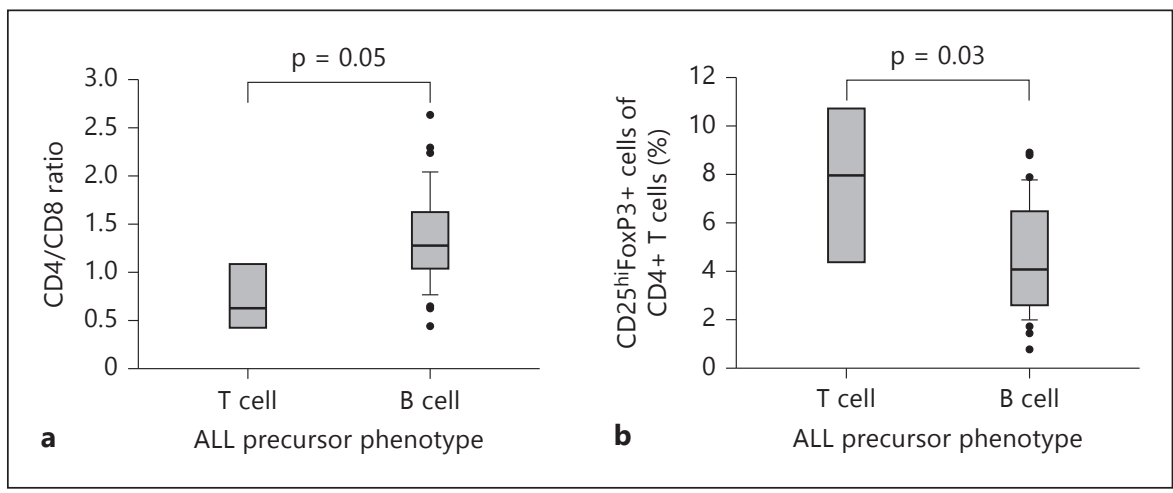

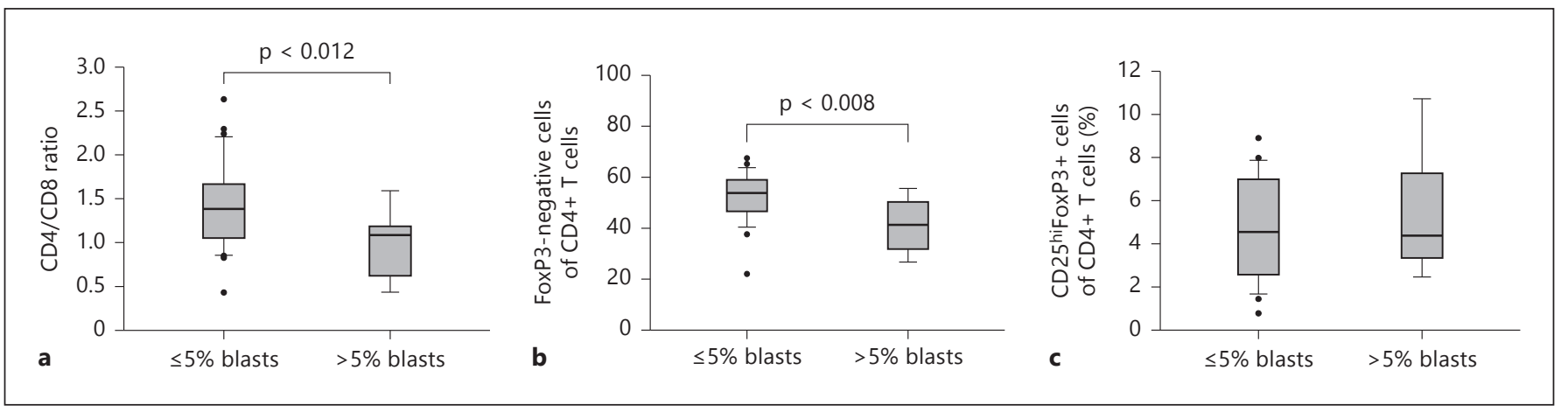

Fig. 4. $C D 4+$ non $-T_{\text {reg }}$ cells at diagnosis were associated with leukemia response on day 15. Ratios of CD4+ to CD8+ T cells (a), CD4+ cells excluding cells with the CD25 hiFoxP3 $+\mathrm{T}_{\text {reg }}$ phenotype (b), and CD4+ cells with the $\mathrm{T}_{\text {reg }}$ phenotype (c) in the BM of patients with $<5 \%$ (M1) and $\geq 5 \%$ (M2, M3) BM blasts on day 15 .

CD4/CD8 Ratios and CD4+ Non- $T_{\text {reg }}$ Cell Proportions Are Associated with Response

To identify prognostically relevant parameters, we analyzed potential associations of individual lymphocyte subsets and leukemia response to treatment. Response parameters were good versus poor response to prednisone, BM blast count $<5 \%$ (M1 status) or $\geq 5 \%$ (M2 or M3) on days 15 and 33 , and risk stratification according to the criteria of the respective treatment protocols [14]. A noticeable association was found between a higher $\mathrm{CD} 4 / \mathrm{CD} 8$ ratio at diagnosis and a favorable BM response on day $15(\mathrm{p}<0.012)$ (fig. 4). A separate analysis of CD4+ cells with the CD4+ $\mathrm{CD} 25^{\text {hi }}$ FoxP $3+\mathrm{T}_{\text {reg }}$ cell phenotype revealed that the association was caused by non- $\mathrm{T}_{\text {reg }} \mathrm{CD} 4+$ cells (fig. 4). No correlation of the $\mathrm{CD} 4 / \mathrm{CD} 8$ ratio with the other response parameters or with relapse was found. Another association by linear regression was a lower ratio of NK cells to $\mathrm{CD} 3+\mathrm{T}$ cells in children with a favorable marrow response on day 15 ( $\mathrm{p}=0.038)$. Neither of the other lymphocyte parameters assessed at the primary diagnosis correlated with response. Among the 31 children who were uniformly risk stratified within the ALL BFM 2000 study, no significant associations between the treatment arm and $\mathrm{CD} 4 / \mathrm{CD} 8$ ratios and non$\mathrm{T}_{\text {reg }} \mathrm{CD} 4+\mathrm{T}$ cell counts were found. To further validate our finding that $\mathrm{CD} 4 / \mathrm{CD} 8$ ratios among residual $\mathrm{T}$ cells in ALL are associated with a favorable early response to therapy, we retrospectively extracted this information from routine diagnostic immunophenotyping analyses in a series of 30 other pediatric patients with ALL, all treated within the AIEOPBFM-ALL 2009 study in our institution (online suppl. table 1; see www.karger.com/doi/10.1159/000351429). Nine of the 30 patients had an unfavorable BM response on day 15 . The association of higher CD4/CD8 ratios with M1 BM response on day 15 of treatment persisted after including these additional patients for a total of 69 patients $(\mathrm{p}=0.028)$.

\section{Discussion}

Mature BM lymphocytes may have special relevance in the control of malignant growth. In murine models, the presence of tumor cells in BM has been associated with 
systemic protection from tumor challenge [22], and tumor-reactive memory $\mathrm{T}$ cells from the BM but not the peripheral blood of solid tumor patients have induced regressions of autologous tumor xenografts in mice [7,23]. In acute leukemias, immune cells in $\mathrm{BM}$ are in direct proximity to the disease as it evolves. Moreover, $\mathrm{T}$ cells circulating in peripheral blood may be recruited into leukemic BM [5]. As a first step towards elucidating their role in childhood ALL, we performed a detailed analysis of the non-leukemic BM lymphocyte compartment at diagnosis.

Besides the clonal population of leukemic lymphoblasts, both $\mathrm{CD} 4+$ and $\mathrm{CD} 8+\mathrm{T}$ cells with naive and central and effector memory phenotypes, as well as the FoxP3+ subset of CD4+ T cells associated with $\mathrm{T}_{\text {reg }}$ cell function, were identified in all patients. The normal distribution of the individual subpopulations compared to healthy children would argue against a relevant role in the disease and support the hypothesis that they represent random bystander cells that have survived leukemic infiltration. Lymphocyte subpopulations are subject to profound age-related changes, and reference values for defined age groups [17] or as continuous values [18] have been obtained for peripheral blood. Our data reproduced several findings in the peripheral blood of healthy children, including the relative increase in antigen-experienced T cells over naive T cells with age [18] and the higher CD4/CD8 ratio in younger children.

However, substantial differences in the composition of lymphocyte subsets between peripheral blood and BM have been reported in healthy normal individuals $[19,24-$ 26]. These studies relied on BM donations from sibling donors, including a few children, or on trephine biopsies obtained during surgery or from volunteers. A major finding was that $\mathrm{BM}$ contains increased numbers of $\mathrm{CD} 8+$ $\mathrm{T}$ cells compared to peripheral blood, resulting in lower CD4/CD8 cell ratios [25, 27-29]. Among BM lymphocytes upon diagnosis of ALL, we found highly variable CD4/CD8 ratios with a median of 1.22 , slightly above that reported for normal BM. One limitation of these studies, including ours, is the inevitable contamination of BM aspirates with blood [30]. Staining of normal lymphocytes in trephine biopsies by immunohistochemistry can avoid this problem, but in acute leukemias it is complicated by the high and locally variable BM expansion of the leukemic clone.

In quantitative studies, a greater gain of information can be expected from correlation of individual lymphocyte parameters with patient-associated variables. The central observation of our study was that higher CD4/
CD8 ratios among residual lymphocytes correlate with a favorable early response. CD4+ effector T cells have previously been attributed an active role in antitumor immunity [31-33], including ALL [34]. It is thus tempting to speculate that $\mathrm{CD} 4+\mathrm{T}$ cells, by providing antigen-specific help to tumor-reactive CD8+ T cells, contribute to the elimination of leukemic lymphoblasts during induction chemotherapy. A larger prospective study is now needed to establish whether the CD4/CD8 ratio is an independent parameter for a favorable response, and functional studies will have to elucidate the role, antigen specificity, and function of $\mathrm{CD} 4+\mathrm{BM}$ T cells in individual subtypes of ALL.

Besides protective immune responses, lymphocytes may actively participate in local immunosuppression within the BM niche. One of the best-defined mechanisms of local tumor immune evasion is the accumulation of $\mathrm{T}$ cells with a regulatory phenotype and suppressive function $[4,35,36]$. BM was shown to be a significant reservoir for regulatory $\mathrm{T}$ cells, with a higher proportion of $\mathrm{CD} 4+\mathrm{CD} 25^{\text {hi }}$ FoxP3 $+\mathrm{T}_{\text {reg }}$ cells than peripheral blood [37]. Here, no evidence was found for a significant general role of $\mathrm{T}_{\text {reg }}$ cells in childhood ALL, but increased proportions of $\mathrm{T}_{\text {reg }}$ cells were found in $\mathrm{T}$ lineage ALL. In a previous study, $\mathrm{T}_{\text {reg }}$ cell numbers were not significantly different in peripheral blood between $\mathrm{B}$ and $\mathrm{T}$ lineage leukemias [38]. Especially due to the low proportions of $\mathrm{T}$ lineage ALL, large numbers of patients will have to be studied in a prospective manner to gain further insights into the role of $\mathrm{T}_{\text {reg }}$ cells in childhood ALL.

Besides antigen-specific $T$ cells, innate immune effector cells have been suggested to contribute to the elimination of cancer cells. The capacity of $\gamma \delta$ T cells to mediate antileukemic immune responses was suggested by an association of $\gamma \delta$ T cells with graft-versus-leukemia effects in transplantation [39]. NKT cells have been suggested to mediate both protective and immunomodulatory functions in various leukemias [40-42]. Neither $\gamma \delta$ T cells nor NKT cells were associated with disease-related parameters or response in our cohort. Moreover, our finding that lower ratios of NK cells to CD3 cells were associated with favorable early responses argues against a major role of this lymphocyte subset in protective immune responses in this setting.

To validate our findings, we now plan to perform a prospective analysis of the CD4/CD8 ratios and of individual lymphocyte subpopulations in diagnostic BM as well as peripheral blood in children with ALL. Larger numbers of patients will be analyzed to establish reliable multiple regression models. To minimize blood contam-
Lustfeld/Altvater/Ahlmann/Ligges/ Brinkrolf/Rosemann/Moericke/Rossig 
ination and avoid variation, we suggest uniform use of the material from the first sample aspirated at a given puncture site. Moreover, future experiments will aim to establish the functional role of the individual $\mathrm{T}$ cell subsets in immune control or escape in pediatric ALL. The capacity of CD4+ and CD8+ T cells isolated from patient BM to functionally interact with leukemic cells will be explored in degranulation and cytokine release assays using autol- ogous leukemic cells as targets. Moreover, the antigen specificity of individual memory CD8+ and CD4+ T cell clones among candidate antigens with known relevance in acute leukemias, e.g. WT-1 [43], PRAME [44], PAX5 [45], and their in vitro reactivity with autologous leukemic blasts will be determined. Together, these insights can contribute to the development of effective immunotherapeutic strategies.

\section{References}

1 Galon J, Costes A, Sanchez-Cabo F, Kirilovsky A, Mlecnik B, Lagorce-Pages C, Tosolini M, Camus M, Berger A, Wind P, Zinzindohoue F, Bruneval P, Cugnenc PH, Trajanoski Z, Fridman WH, Pagès F: Type, density, and location of immune cells within human colorectal tumors predict clinical outcome. Science 2006;313:1960-1964.

-2 Koebel CM, Vermi W, Swann JB, Zerafa N, Rodig SJ, Old LJ, Smyth MJ, Schreiber RD: Adaptive immunity maintains occult cancer in an equilibrium state. Nature 2007;450:903907.

3 Pages F, Berger A, Camus M, Sanchez-Cabo F, Costes A, Molidor R, Mlecnik B, Kirilovsky A, Nilsson M, Damotte D, Meatchi T, Bruneval P, Cugnenc PH, Trajanoski Z, Fridman WH, Galon J: Effector memory T cells, early metastasis, and survival in colorectal cancer. N Engl J Med 2005;353:2654-2666.

-4 Curiel TJ, Coukos G, Zou L, Alvarez X, Cheng P, Mottram P, Evdemon-Hogan M, ConejoGarcia JR, Zhang L, Burow M, Zhu Y, Wei S, Kryczek I, Daniel B, Gordon A, Myers L, Lackner A, Disis ML, Knutson KL, Chen L, Zou W: Specific recruitment of regulatory $\mathrm{T}$ cells in ovarian carcinoma fosters immune privilege and predicts reduced survival. Nat Med 2004;10:942-949.

5 Di Rosa F, Pabst R: The bone marrow: a nest for migratory memory $\mathrm{T}$ cells. Trends Immunol 2005;26:360-366.

-6 Dhodapkar MV, Krasovsky J, Osman K, Geller MD: Vigorous premalignancy-specific effector $\mathrm{T}$ cell response in the bone marrow of patients with monoclonal gammopathy. J Exp Med 2003;198:1753-1757.

7 Feuerer M, Beckhove P, Bai L, Solomayer EF, Bastert G, Diel IJ, Pedain C, Oberniedermayr M, Schirrmacher V, Umansky V: Therapy of human tumors in NOD/SCID mice with patient-derived reactivated memory $\mathrm{T}$ cells from bone marrow. Nat Med 2001;7:452458.

8 Letsch A, Keilholz U, Assfalg G, Mailander V, Thiel E, Scheibenhogen C: Bone marrow contains melanoma-reactive $\mathrm{CD} 8(+)$ effector $\mathrm{T}$ cells and, compared with peripheral blood, enriched numbers of melanoma-reactive CD8(+) memory T cells. Cancer Res 2003;63: 5582-5586.
9 Barbaric D, Wynne K, Aslanian S, Bond M, Reid GS: Immune evasion strategies of pediatric precursor-B acute lymphoblastic leukemia after allogeneic bone marrow transplantation - a case study. Leuk Res 2005;29:711714 .

10 Glouchkova L, Ackermann B, Zibert A, Meisel R, Siepermann M, Janka-Schaub GE, Goebel U, Troeger A, Dilloo D: The CD70/ $\mathrm{CD} 27$ pathway is critical for stimulation of an effective cytotoxic $\mathrm{T}$ cell response against $\mathrm{B}$ cell precursor acute lymphoblastic leukemia. J Immunol 2009;182:718-725.

11 Gros F, Sebti Y, de Guibert S, Branger B, Bernard M, Fauchet R, Amiot L: Soluble HLA-G molecules increase during acute leukemia, especially in subtypes affecting monocytic and lymphoid lineages. Neoplasia 2006;8:223230.

12 Romanski A, Bug G, Becker S, Kampfmann M, Seifried E, Hoelzer D, Ottmann OG, Tonn $\mathrm{T}$ : Mechanisms of resistance to natural killer cell-mediated cytotoxicity in acute lymphoblastic leukemia. Exp Hematol 2005;33:344352.

13 Troeger A, Glouchkova L, Ackermann B, Escherich G, Meisel R, Hanenberg H, den Boer ML, Pieters R, Janka-Schaub GE, Goebel U, Laws HJ, Dilloo D: High expression of CD40 on B-cell precursor acute lymphoblastic leukemia blasts is an independent risk factor associated with improved survival and enhanced capacity to up-regulate the death receptor CD95. Blood 2008;112:1028-1034.

14 Moricke A, Reiter A, Zimmermann M, Gadner $\mathrm{H}$, Stanulla M, Dordelmann M, Loning L, Beier R, Ludwig WD, Ratei R, Harbott J, Boos J, Mann G, Niggli F, Feldges A, Henze G, Welte K, Beck JD, Klingebiel T, Niemeyer C, Zintl F, Bode U, Urban C, Wehinger H, Niethammer D, Riehm H, Schrappe M: Risk-adjusted therapy of acute lymphoblastic leukemia can decrease treatment burden and improve survival: treatment results of 2,169 unselected pediatric and adolescent patients enrolled in the trial ALL-BFM 95. Blood 2008; 111:4477-4489.

15 Conter V, Bartram CR, Valsecchi MG, Schrauder A, Panzer-Grumayer R, Moricke A, Arico M, Zimmermann M, Mann G, De RG, Stanulla M, Locatelli F, Basso G, Niggli F,
Barisone E, Henze G, Ludwig WD, Haas OA, Cazzaniga G, Koehler R, Silvestri D, Bradtke J, Parasole R, Beier R, van Dongen JJ, Biondi A, Schrappe M: Molecular response to treatment redefines all prognostic factors in children and adolescents with B-cell precursor acute lymphoblastic leukemia: results in 3,184 patients of the AIEOP-BFM ALL 2000 study. Blood 2010;115:3206-3214.

16 Brinkrolf P, Landmeier S, Altvater B, Chen C, Pscherer S, Rosemann A, Ranft A, Juergens H, Dirksen U, Rossig C: A high proportion of bone marrow $\mathrm{T}$ cells with regulatory pheno-

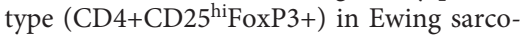
ma patients is associated with metastatic disease. Int J Cancer 2009;125:879-886.

17 Comans-Bitter WM, de Groot R, van den Beemd R, Neijens HJ, Hop WC, Groeneveld $\mathrm{K}$, Hooijkaas H, van Dongen JJ: Immunophenotyping of blood lymphocytes in childhood: reference values for lymphocyte subpopulations. J Pediatr 1997;130:388-393.

18 Huenecke S, Behl M, Fadler C, Zimmermann SY, Bochennek K, Tramsen L, Esser R, Klarmann D, Kamper M, Sattler A, von $L D$, Klingebiel T, Lehrnbecher T, Koehl U: Agematched lymphocyte subpopulation reference values in childhood and adolescence: application of exponential regression analysis. Eur J Haematol 2008;80:532-539.

19 Rego EM, Garcia AB, Viana SR, Falcao RP: Age-related changes of lymphocyte subsets in normal bone marrow biopsies. Cytometry 1998;34:22-29.

20 Sallusto F, Lenig D, Forster R, Lipp M, Lanzavecchia A: Two subsets of memory T lymphocytes with distinct homing potentials and effector functions. Nature 1999;401:708-712.

-21 Tosello V, Odunsi K, Souleimanian NE, Lele S, Shrikant P, Old LJ, Valmori D, Ayyoub M: Differential expression of CCR7 defines two distinct subsets of human memory CD4+CD25+ Tregs. Clin Immunol 2008; 126:291-302.

22 Khazaie K, Prifti S, Beckhove P, Griesbach A, Russell S, Collins M, Schirrmacher V: Persistence of dormant tumor cells in the bone marrow of tumor cell-vaccinated mice correlates with long-term immunological protection. Proc Natl Acad Sci USA 1994;91: 7430-7434. 
23 Beckhove P, Feuerer M, Dolenc M, Schuetz F, Choi C, Sommerfeldt N, Schwendemann J, Ehlert K, Altevogt P, Bastert G, Schirrmacher V, Umansky V: Specifically activated memory $T$ cell subsets from cancer patients recognize and reject xenotransplanted autologous tumors. J Clin Invest 2004;114:67-76.

24 Andreoni C, Rigal D, Bonnard M, Bernaud J: Phenotypic analysis of a large number of normal human bone marrow sample by flow cytometry. Blut 1990;61:271-277.

25 Clark P, Normansell DE: Phenotype analysis of lymphocyte subsets in normal human bone marrow. Am J Clin Pathol 1990;94:632-636.

26 Fauci AS: Human bone marrow lymphocytes. 1. Distribution of lymphocyte subpopulations in the bone marrow of normal individuals. J Clin Invest 1975;56:98-110.

-27 Palendira U, Chinn R, Raza W, Piper K, Pratt G, Machado L, Bell A, Khan N, Hislop AD, Steyn R, Rickinson AB, Buckley CD, Moss P: Selective accumulation of virus-specific CD8(+) T cells with unique homing phenotype within the human bone marrow. Blood 2008;112:3293-3302.

28 Thaler J, Greil R, Dietze O, Huber H: Immunohistology for quantification of normal bone marrow lymphocyte subsets. Br J Haematol 1989;73:576-577.

29 Zhang X, Dong H, Lin W, Voss S, Hinkley L, Westergren M, Tian G, Berry D, Lewellen D, Vile RG, Chen L, Farber DL, Strome SE: Human bone marrow: a reservoir for 'enhanced effector memory' CD8+ T cells with potent recall function. J Immunol 2006;177:6730-6737.

- 30 Clark P, Normansell DE, Innes DJ, Hess CE: Lymphocyte subsets in normal bone marrow. Blood 1986;67:1600-1606.

- 31 Corthay A, Skovseth DK, Lundin KU, Rosjo E, Omholt H, Hofgaard PO, Haraldsen G, Bogen B: Primary antitumor immune response mediated by CD4+ T cells. Immunity 2005 ; 22:371-383.
Hung K, Hayashi R, Lafond-Walker A, Lowenstein C, Pardoll D, Levitsky H: The central role of CD4(+) T cells in the antitumor immune response. J Exp Med 1998;188:23572368.

-33 Mumberg D, Monach PA, Wanderling S, Philip M, Toledano AY, Schreiber RD, Schreiber $\mathrm{H}$ : $\mathrm{CD} 4(+) \mathrm{T}$ cells eliminate $\mathrm{MHC}$ class II-negative cancer cells in vivo by indirect effects of IFN-gamma. Proc Natl Acad Sci USA 1999;96:8633-8638.

34 Hegazy AN, Klein C: Ex vivo priming of CD4 $\mathrm{T}$ cells converts immunological tolerance into effective antitumor immunity in a murine model of acute lymphoblastic leukemia. Leukemia 2008;22:2070-2079.

35 Beyer M, Kochanek M, Giese T, Endl E, Weihrauch MR, Knolle PA, Classen S, Schultze JL: In vivo peripheral expansion of naive CD4+CD25 $5^{\text {high }}$ FoxP3+ regulatory $\mathrm{T}$ cells in patients with multiple myeloma. Blood 2006; 107:3940-3949.

- 36 Motta M, Rassenti L, Shelvin BJ, Lerner S, Kipps TJ, Keating MJ, Wierda WG: Increased expression of CD152 (CTLA-4) by normal T lymphocytes in untreated patients with B-cell chronic lymphocytic leukemia. Leukemia 2005; 19:1788-1793.

-37 Zou LH, Barnett B, Safah H, Larussa VF, Evdemon-Hogan M, Mottram P, Wei SN, David $\mathrm{O}$, Curiel TJ, Zou WP: Bone marrow is a reservoir for $\mathrm{CD} 4(+) \mathrm{CD} 25(+)$ regulatory $\mathrm{T}$ cells that traffic through CXCL12/CXCR4 signals. Cancer Res 2004;64:8451-8455.

- 38 Wu CP, Qing X, Wu CY, Zhu H, Zhou HY: Immunophenotype and increased presence of $\mathrm{CD} 4(+) \mathrm{CD} 25(+)$ regulatory $\mathrm{T}$ cells in patients with acute lymphoblastic leukemia. Oncol Lett 2012;3:421-424.
39 Godder KT, Henslee-Downey PJ, Mehta J, Park BS, Chiang KY, Abhyankar S, Lamb LS: Long term disease-free survival in acute leukemia patients recovering with increased gammadelta $T$ cells after partially mismatched related donor bone marrow transplantation. Bone Marrow Transplant 2007;39:751-757.

40 Gibson SE, Swerdlow SH, Felgar RE: Natural killer cell subsets and natural killer-like T-cell populations in benign and neoplastic B-cell proliferations vary based on clinicopathologic features. Hum Pathol 2011;42:679-687.

41 Jadidi-Niaragh F, Jeddi-Tehrani M, Ansaripour B, Razavi SM, Sharifian RA, Shokri F: Reduced frequency of NKT-like cells in patients with progressive chronic lymphocytic leukemia. Med Oncol 2012;29:3561-3569.

42 Sconocchia G, Lau M, Provenzano M, Rezvani $\mathrm{K}$, Wongsena W, Fujiwara $\mathrm{H}$, Hensel N, Melenhorst J, Li J, Ferrone S, Barrett AJ: The antileukemia effect of HLA-matched NK and NK-T cells in chronic myelogenous leukemia involves NKG2D-target-cell interactions. Blood 2005; 106:3666-3672.

43 Boublikova L, Kalinova M, Ryan J, Quinn F, O'Marcaigh A, Smith O, Browne P, Stary J, McCann SR, Trka J, Lawler M: Wilms' tumor gene 1 (WT1) expression in childhood acute lymphoblastic leukemia: a wide range of WT1 expression levels, its impact on prognosis and minimal residual disease monitoring. Leukemia 2006:20:254-263.

44 Van BN, Chambost H, Ferrant A, Michaux L, Ikeda H, Millard I, Olive D, Boon T, Coulie PG: PRAME, a gene encoding an antigen recognized on a human melanoma by cytolytic $\mathrm{T}$ cells, is expressed in acute leukaemia cells. $\mathrm{Br}$ J Haematol 1998;102:1376-1379.

45 Yan M, Himoudi N, Pule M, Sebire N, Poon E, Blair A, Williams O, Anderson J: Development of cellular immune responses against PAX5, a novel target for cancer immunotherapy. Cancer Res 2008;68:8058-8065. 